knowledged debt to Jürgen Hentze's Internationalismus und Klassenkampf: Die polnischen Schriften (1971). Placing the proofs for a single afternoon in the hands of any one of the able translators of the Polish works would have sufficed to eliminate this last problem.

Davis, in his introduction, argues a present relevancy for Luxemburg and her ideas which this reviewer-with all his respect for her as a historical personage-finds difficult to accept. That she was deserted by her masses in August 1914 is common knowledge; her dismay and despair at the prospect is also well known. Less familiar is a similar desertion by her Polish masses in the years following 1905 . Her fulminations against the National Democratic Party and Roman Dmowski (pp. 177-82) can be viewed in light of the occurrence of these events only shortly before. Events would seem to have overtaken her ideas not only in Poland and Germany ("Peasants do not sink. . ..") but elsewhere as well. Perhaps this is why the Dmowski of this period has-from Sir Bernard Pares onward-commanded a greater appeal to the English and American political mind than has Luxemburg.

The editor and translators have produced a consistently readable text and are to be congratulated on their common effort. A complete and scholarly edition, however, still eludes us.

Alvin M. Fountain II Raleigh, North Carolina

\title{
MARCH 1939, THE BRITISH GUARANTEE TO POLAND: A STUDY IN THE CONTINUITY OF BRITISH FOREIGN POLICY. By Simon Newman. Oxford: Clarendon Press, 1976: viii, 253 pp. $\$ 14.25$.
}

Simon Newman has written a detailed account of the British guarantee to Poland, which was issued on March 31, 1939. His well-documented study, based on the newly opened materials in the Public Record Office, is an important revisionist interpretation of the reasons and the circumstances which led to the guarantee.

To Newman, the guarantee stemmed from the decline in British power and from the frantic search for some means to preserve Britain's position. At the same time, there was the urgent need to halt German expansion in eastern Europe by all means short of war, and if necessary, by war itself.

Unwilling to grant Germany a free hand in eastern Europe, the Chamberlain government tried unsuccessfully to block the German drive to the east by economic means. Then Chamberlain's hopes for rapprochement with Germany, while maintaining the status quo in eastern Europe, were wrecked when Moravia and Bohemia were occupied on March 15, 1939.

In Whitehall, the reports of German pressure on Rumania to make economic concessions prompted concern for Britain's security because control of Rumania would enable Germany to evade a British blockade in wartime. As a result of these reports, Halifax and Chamberlain sought a public declaration from Moscow, Paris, and Warsaw to consult with London over offering joint resistance to any action which threatened the political independence of any European state. This four power declaration was never issued because the Polish government refused to be associated publicly with the Soviet Union.

Newman contends that Halifax, fearful that Britain's position would be ruined if the eastern European nations submitted to Hitler's demands, devised the unconditional guarantee of Poland. Such a guarantee would strengthen Polish resistance to German threats and prevent any German-Polish deal over Danzig. The guarantee was hammered out, Newman argues, at a time when no German threat to Poland existed.

Moreover, according to Newman, the guarantee was a direct challenge to Hitler, 
and it not only prevented serious negotiations but led to the outbreak of war. Thus, Newman contends that in essence World War II was started by Lord Halifax and others in the Foreign Office who recognized the risk and accepted the inevitability of war. They chose deliberately to challenge Hitler through the Polish guarantee and they were aware of the consequences of this action.

Newman's argument is based primarily on statements by Halifax which are limited in number and open to interpretation. They are insufficient to support fully his contention that the guarantee was a deliberate challenge and that the British leaders fully grasped the consequences of their action. Newman ignores statements by Halifax and Chamberlain that the guarantee was intended as a deterrent, a means of bringing Hitler up short, compelling him to return to the negotiating table. Nor does Newman present sufficient evidence to show a cold-blooded decision to use the guarantee as a pretext for war. If anything, Newman proves conclusively how completely the Chamberlain government misread the situation and failed to understand the consequences of the guarantee.

Although Newman's conclusions are debatable, his book offers a thorough examination of this question. It is an important contribution to the study of the outbreak of World War II. All serious students of the history of this conflict must read Newman's book even though they may argue with him over his interpretation of the evidence.

\section{Keith Eubank Queens College, CUNY}

\section{NEO-SLAVISM AND THE CZECHS 1898-1914. By Paul Vyšný. Soviet and East European Studies. Cambridge: Cambridge University Press, 1977. xiv, 287 pp. $\$ 21.95$.}

Paul Vyšnýs interesting, well-written volume offers a valuable treatment of NeoSlavism, a short-lived but significant movement that sought to promote Slavic cooperation, particularly between Czechs and Russians. The movement was an ideological amalgam of Austro-Slavism, Czech Russophilism, Russian Pan-Slavism, and the special perspectives of Poles and South Slavs. Its creator and main driving force was the Czech politician, Karel Kramár ; at its zenith in 1908-10, the leaders and adherents included the Czechs V. Klofač and J. Preiss; the Russians V. A. Bobrinskii, V. A. Maklakov, and A. I. Guchkov; the Pole R. Dmowski; and the Slovene I. Hribar. Among the many objectives of the Neo-Slav movement were united political action by Slavs in Austria, better treatment of Poles in Russia, the creation of an international Slav bank, and the organization of a Slav industrial and trade exhibition in Moscow. The movement also became involved with the principal diplomatic problem of the period-the tinderbox of the Balkans. Despite its brief existence and ultimate failure, the movement engaged many prominent politicians and addressed the major issues of concern to Slavs. Nevertheless, apart from an unpublished Austrian dissertation (O. Heinz, "Der Neoslawismus," University of Vienna, 1963) and a few scattered articles, Neo-Slavism has not been the subject of serious study; even the standard Czech histories of the period give it scant attention.

Vyšný's book goes far toward filling this gap. Drawing mainly upon printed sources (memoirs, congress protocols, the Kramár trial proceedings, newspapers) and a few archival materials (in Vienna and London), he has written a lucid political history of Neo-Slavism and provides a reliable account of its origins, program, activities, internal conflicts, and diplomatic complications. Separate chapters are devoted to the Neo-Slav congresses in Prague (1908) and Sofia (1910), giving a detailed account of their participants, achievements, and impact. Insofar as his sources allow, 